$\left(\begin{array}{ccc}\text { Jpn. J. Hosp. Pharm. } & \stackrel{i}{-} \\ 26(2) & 207-211 & (2000)\end{array}\right)$

\title{
ミコナゾール・ゲルとワルファリンとの重篤な相互作用
}

五十嵐正博 ${ }^{*} \dagger^{1}$, 黒岩朝子 $\dagger^{1}$, 林 昌洋 $\dagger^{1}$,

灰田美知子 $\dagger^{2}$ ，峯村信嘉 $\dagger^{3}$, 高木英爾 $\dagger^{3}$, 西山信一郎 $\dagger^{3}$, 百村伸一 $\dagger^{3}$

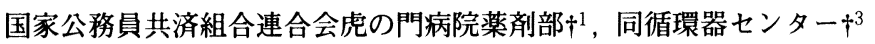

医療法人社団茂恵会 半藏門病院 $\dagger^{2}$

\section{Serious Interaction between Miconazole Gel and Warfarin}

\author{
MASAHIRO IGARASHI ${ }^{*} \dagger^{1}$, ASAKO KUROIWA $\dagger^{1}$, MASAHIRO HAYASHI $\dagger^{1}$, \\ MICHIKO HAIDA $\dagger^{2}$, NOBUYOSHI MINEMURA $\dagger^{3}$, EIJI TAKAGI $\dagger^{3}$, \\ SHINICHIROU NISHIYAMA $\dagger^{3}$ and SHINICHI MOMOMURA $\dagger^{3}$ \\ Department of Pharmacy $\dagger^{+1}$ and Division of Cardiology, Cardiovascular Center $\dagger^{3}$, \\ Toranomon Hospital \\ Hanzoumon Hospital $\dagger^{2}$
}

$\left(\begin{array}{l}\text { Received June 14, } 1999 \\ \text { Accepted January 5, } 2000\end{array}\right)$

We experienced a serious interaction between miconazole gel and warfarin. The patient had just undergone an aortic and mitral value replacement and thus was medicated with warfarin at a dosage according to the International Normalized Ratio (INR) of about 2.0-2.5. He was prescribed miconazole gel $400 \mathrm{mg} /$ day for thrush induced by steroid for asthma. About two weeks later, he showed bleeding in the mouth and underwent a medical examination. His INR was higher than the upper of measurement limit and so he was immediately hospitalized. Vitamin $\mathrm{K}$ was given, miconazole gel and warfarin ware stopped. Two weeks later, his INR was less than 3.0 and thus the warfarin was restarted. But his warfarin dose was less than one third of dose that had been given before hospitalization.

The interaction between miconazole gel and warfarin that we experienced by our patient while was as serious as the reports from abroad.

Key words - miconazole gel, warfarin, drug interaction, human, case report

緒言

ミコナゾール・ゲルは，体内にほとんど吸収さ

$\dagger^{1.3}$ 港区虎ノ門 2-2-2；2-2-2, Toranomon, Minato-ku, Tokyo, 105-8470 Japan

$\dagger^{2}$ 千代田区靝町1-10-5;1-10-5, Koujimachi, Chiyoda-ku, Tokyo, 102-0083 Japan
れないため安全性が高い1) とされているが，添付 文書にはミコナゾール・ゲルとワルファリンとの 併用は慎重投与と記載されている2,3)。文献を調 查したところ，ミコナゾール・ゲルとワルファリ ンとの併用により相互作用が発現した症例が海外 では複数報告されていたが得，本邦では報告さ れていなかった。 
今回われわれは，ワルファリン服用患者がミコ ナゾール・ゲルを経口服用後, 相互作用を起こし 緊急入院となった症例を経験した。本症例の臨床 経過を中心にミコナゾール・ゲルとワルファリン の相互作用について報告する。

\section{症例}

症例は，弁置換術後ワルファリンを服用してい た52歳男性。うっ血性心不全と気管支喘息などに 対し，ジゴキシン $0.25 \mathrm{mg} /$ 日，ジピリダモール 150 $\mathrm{mg} /$ 日，トリアムテレン $50 \mathrm{mg} /$ 日, フロセミド 20 $\mathrm{mg} /$ 日, アズレンスルフォン酸ナトリウム・Lグ ルタミン $2 \mathrm{~g} /$ 日, ベラパミル $120 \mathrm{mg} /$ 日, ベタメ タゾン $0.5 \mathrm{mg}$ 隔日を服用していた。ワルファリ ンのコントロールは International Normalized Ratio （INR）の治療域が 2.0-2.5 のところ, 測定 INR が 2.0 付近と安定していた（Fig. 1).

3 月18日，喘息に対して服用していたステロイ ド剤による口腔カンジダ症に対し，ミコナゾール。 ゲル300-400mg/日の服用を開始した。3 月19日 の外来では, INR は2.2と治療域であったが，4 月 1 日夜から口腔内の出血が止まらなくなった. このため 4 月 2 日に来院したところ, INR は測定
不能（10以上）であることが判明した（Fig. 1$)$. このため, ただちにビタミン $\mathrm{K} を 10 \mathrm{mg}$ 静注, 相 互作用の疑われたミコナゾール・ゲルとワルファ リンを中止し緊急入院となった。入院時，血液凝 固系以外の検査值には特に異常は認められなかっ た (Table 1$)$.

入院 2 日目, INR は 2.1 まで低下したため, 入 院前の約半量であるワルファリン $3 \mathrm{mg}$ 存開始した.と ころが，INR は入院 3 日目 4.9，4 日目8.6と上 昇し，4 日目以降ワルファリンを再度中止した。

入院13日目（4月14日）にINR は 3 未満となっ たため, ワルファリンを再開した。その後, 入院 前の約 $1 / 3$ の量である 1 日 $2 \mathrm{mg}$ の処方で26日 目に退院となった (Fig. 1)。退院日はミコナゾー ル・ゲル中止後約 4 週間経過していたが，ワルフ アリンの投与量は併用前の 3 分の 1 以下であった ため, 退院後も外来での慎重な経過観察を行うこ ととなった。

その後 $1-2$ 週間おきの外来受診によりワルフ アリンの投与量は徐々に増量され，7月 2 日の外 来受診時に，入院前とほぼ同じワルファリン 1 日 $6 \mathrm{mg}$ に戻った。したがって，この症例に抢いて ミコナゾールゲル中止からワルファリン投与量が

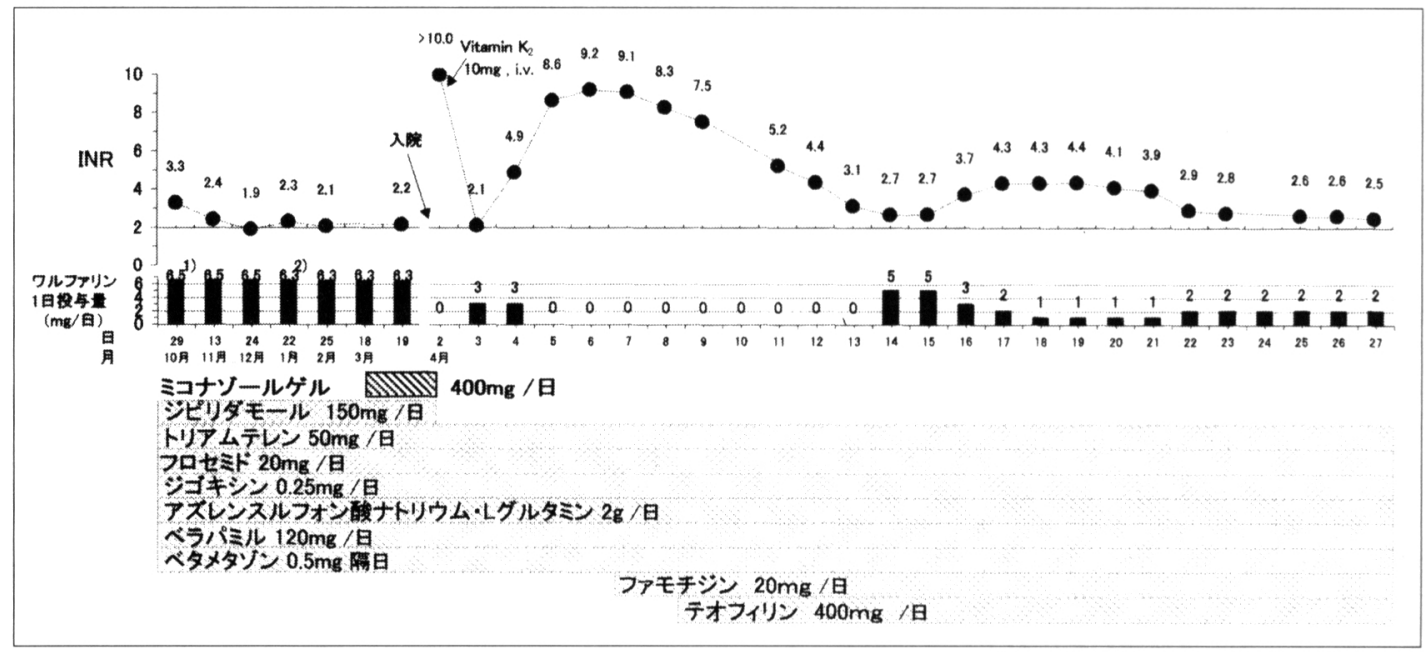

Fig. 1. ワルファリン服用量および併用薬剂と INR の推移

1） 1 日， $6 \mathrm{mg} ， 7 \mathrm{mg}$ のくり返しで服用

2） 1 日， $6 \mathrm{mg}, 6 \mathrm{mg}, 7 \mathrm{mg}$ のくり返しで服用 
Table 1. 入院時所見

\begin{tabular}{|c|}
\hline 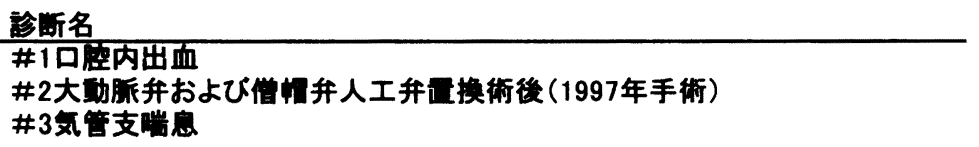 \\
\hline 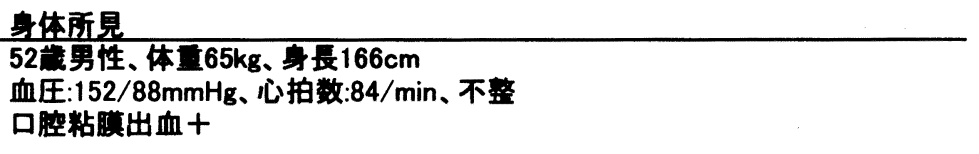 \\
\hline 険奎所見 \\
\hline 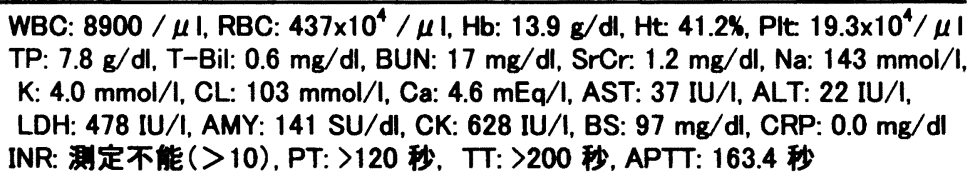 \\
\hline
\end{tabular}

併用前の投与量で安定するまでの期間は, 約 3 力 月であった。

\section{考察}

海外ではミコナゾール $522 \mathrm{mg}$ 経口投与での ピーク濃度は $370 \mathrm{ng} / \mathrm{mL}$ と報告されており ${ }^{14)}$, バ イオアベイラビリティーは約 $27 \%$ 程度と報告され ている ${ }^{14)}$. 本邦での報告では，この報告の約 $1 / 5$ の投与量であるミコナゾール・ゲル $100 \mathrm{mg}$ 投与 で，血漿中に薬物は検出されていない1)。これは 検出限界が $100 \mathrm{ng} / \mathrm{mL}$ の測定法1)を用いたためと 考えられる。したがってミコナゾール・ゲルとワ ルファリンとの相互作用をミコナゾール・ゲルの 吸収率から否定することはできないと考えられ た.

一方，健常人 6 人を対象にしたミコナゾールと ワルファリンの相互作用に関する検討では，ミコ ナゾール錠 $150 \mathrm{mg} /$ 日を 3 日間服用したところ全 員においてプロトロンビン時間は延長し, 併用前 の約 5 倍相当 (平均) となっている ${ }^{13)}$. 最終服用 24 時間後 6 人のミコナゾール血漿中濃度は3, $4,5,7,20,26 \mathrm{ng} / \mathrm{mL}$ であり ${ }^{13)}$, 本邦での吸収 率の報告1)における検出限界以下のミコナゾール 漂度でワルファリンと相互作用を起こす可能性が 考えられた.さらに, この報告でのミコナゾール 錠150mg/日という投与量は, 本邦でのミコナゾー ル・ゲルの投与量 $200 \mathrm{mg}-400 \mathrm{mg} /$ 日 $^{2)}$ の下限以下 の投与量である.したがってこの報告は，ミコナ ゾール・ゲルを本邦での投与量で経口投与して も，ミコナゾール錠と同様にワルファリンと相互 作用が起きる可能性があることを示している．実 際に，ミコナゾール・ゲルとワルファリンとの重 篤な相互作用は海外にて複数報告されてお $り^{4-10)}$ ，本邦での投与量よりも少ない $100 \mathrm{mg} /$ 日で の症例報告もある9（Table 2$)$ 。これらの症例報告 は, 前述の報告13) と一致するものと考えられた。

この相互作用発現機序はワルファリンの代謝を 行う肝ミクロゾームの代謝阻害によるものとされ ており, ワルファリンのクリアランスはミコナ ゾール併用によって約 $1 / 3$ になる ${ }^{13)}$. 特にワル ファリンの活性体の 1 つである $\mathrm{S}$ 体の代謝を担 う CYP 2 C 9 を阻害し, S-ワルファリンのクリア ランスを約 $80 \%$ 減少させると報告されている ${ }^{13)}$.

今回報告した症例については, ミコナゾール． ゲルの併用後約 2 週間で INR が上昇し, 中止約 2 週間後に INR は 3.0 以下に低下した。 また入 院前後に服用していたミコナゾール・ゲル以外の 薬剤については, INRの変動を起こす可能性のあ る薬片は認められず15-17)，INRが上昇した時期に 処方変更された薬剤もなかった。したがってこの 
Table 2. ワルファリン服用患者におけるミコナゾール・ゲル併用による INR の変化 (文献報告) *

\begin{tabular}{|c|c|c|c|c|c|c|}
\hline $\begin{array}{r}\text { ミコナ’ } \\
\text { 1日投与量 }\end{array}$ & $\begin{array}{l}\text { レ・ゲル } \\
\text { 併用期间 }\end{array}$ & $\begin{array}{l}\text { ワルファリン } \\
\text { 1日股用量 }\end{array}$ & $\begin{array}{c}\text { 併用前 } \\
\text { INR }\end{array}$ & $\begin{array}{c}\text { 併用後 } \\
\text { INR } \\
\end{array}$ & $\begin{array}{c}\text { 併用中止後 } \\
\text { INR安定までの期间 } \\
\end{array}$ & Reference \\
\hline $500 \mathrm{mg}$ & 14 days & $1 \sim 3 \mathrm{mg}$ & 1.5 & $>10$ & 14 days & Ariyarantnam, ot al ${ }^{4}$ \\
\hline- & 7 days & $2 \sim 4 \mathrm{mg}$ & $2.3 \sim 3.5$ & $>15$ & - & Ezsias, ot al ${ }^{5)}$ \\
\hline $500 \mathrm{mg}$ & 10 days & $1 \mathrm{mg}$ & 2.5 & 17.9 & - & Colquhoun, ot $\mathrm{al}^{6)}$ \\
\hline $500 \mathrm{mg}$ & 10 days & $6 \mathrm{mg}$ & 3.4 & $>17$ & 17 days & Pemberton, et al 7$)$ \\
\hline $500 \mathrm{mg}$ & 14 days & $1 \sim 3 \mathrm{mg}$ & 1.5 & $>10$ & 30 days & \\
\hline $500 \mathrm{mg}$ & 14 days & constant dose & stable & $\begin{array}{c}\text { significantly } \\
\text { olevated }\end{array}$ & several weeks & \\
\hline- & 11 days & $7 \sim 8 \mathrm{mg}$ & $2 \sim 3.3$ & 13.1 & 14 days & Shenfield ot al \\
\hline $100 \mathrm{mg}$ & 7 days & $10 \mathrm{mg}$ & $2 \sim 3$ & 10 & - & Pillans, ot $\mathrm{al}^{9)}$ \\
\hline- & 15 days & $5 \mathrm{mg}$ & 1.7 & 9.7 & - & \\
\hline - & 13 days & $3.5 \mathrm{mg}$ & 2.2 & 18 & - & \\
\hline- & 7 days & $4 \mathrm{mg}$ & stable & 12 & - & \\
\hline- & 14 days & $1 \mathrm{mg}$ & stable & 7.5 & - & \\
\hline- & 14 days & - & stable & 20 & - & Evans $^{10)}$ \\
\hline- & 7 days & - & stable & 11.4 & - & \\
\hline
\end{tabular}

症例は, 海外の症例報告4-12) と同様にミコナゾー ル・ゲルとワルファリンとの相互作用の結果, INR が上昇したものと考えられた。なお，ミコナ ゾール・ゲルを服用開始した翌日である 3 月19日 に測定したINRには，変化が見られていない． これは，相互作用の機序がワルファリンの代謝阻 害であるため，1 日経過しただけではワルファリ ンの蓄積に至っていないためと考えられた.

また，この症例では，ワルファリン投与量がミ コナゾール・ゲル併用前の投与量で安定するまで 約 3 カ月の期間が必要だった。海外の症例報告で も併用中止後, INR が安定するまでに数週間の期 間を要することが報告されており 4,7,8) (Table 2)， この症例も相互作用が発現しつづけていた可能性 があると考えられた。

以上のように，この症例の臨床経過は，「ミコ ナゾール・ゲルとワルファリンによる相互作用は 発現率が高く ${ }^{13)}$, 重篤で ${ }^{4-13)}$, 数週間持続する $\left.{ }^{4,7,8)}\right\rfloor$ という海外の文献報告と一致した。このため，ミ コナゾール・ゲルとワルファリンは併用を避ける ベきであると考えられた.

\section{引用文献}

1）大西明弘, 大澤伸雄, 井田圭一, 中井康博, 基 礎と臨床, 27 (1),195-201 (1993).

2）フロリードゲル経口用添付文書，1998. 3月改訂 版.

3） ワーファリン錠添付文書, 1998. 7月改訂版.

4) S.Ariyarantnam, N.S.Thakker, P Sloan, MH, BMJ, 314, (1), 349 (1997).

5) A. Ezsias, F.Wojnarowska, R.Juniper Dent. Update, 24, 421-422 (1997).

6) M.C.Colquhoun, M.Daly, P Stewart, L.Beeley, Lancet, 1, 695-696 (1987).

7) M.N. Pemberton, P.Sloan, S.Ariyarantnam, N. S.Thakker, M.H.Thornhill, British Dental Journal, 184, (2), 68-69 (1998).

8) G.M.Shenfield, M.Page, Aust. NZ J Med., 21, (6),928 (1991).

9) P. Pillans, DJ Woods, New Zealand Medical Journal, 346 (1996).

10) Jonathan Evans, David S Orme, Mertin L Sedgwick, Giles R Youngs, British Dental Journal, 182, (12), 452 (1997).

11) Elaine Long, Warfarin-Miconazole Interaction, Arch. Intern. Med ., 143, 2214-2215 (1983).

12) P.G. Watson, R.G.Lochan, V.J.Redding, $B M J$, 285 (9), 1045-1046 (1982).

13) Robert A. O'Reilly, Darklis A. Goulart, Kent L.Kunze, John Neal, Milo Gibaldi, Craig 
Eddy, William F. Trager, Clin. Pharmaco. Ther., 51, 656-667 (1992).

14) T.K. Daneshmend, D.W.Warnock, Clinical Pharmacokinetics, 8, 17-42 (1983).

15) Philip D. Hansten, John R. Horn, "Drug interactions.Analysis and manegement", Applied
Thera-peutics, Inc., Vancouver, 1997.

16) Ivan H. Stockley, "Drug Interactions", third editon, Blackwell Scientific Publications, Inc., Cam-bridge, 1994.

17）厚生省薬務局企画課, ”医薬品相互作用ハンド ブック”, 薬業時報社, 東京, 1994 . 